\title{
ON THE LARVA AND PUPA OF A PARASITIC PHORID FLY-HYPOCERA INCRASSATA MG.
}

\author{
BY HUBERT M. MORRIS, M.Sc., F.E.S. \\ (Entomological Dept., Institute of Plant Pathology, Rothamsted \\ Experimental Station, Harpenden.)
}

(Plate III and 4 Text-figures.)

\begin{tabular}{|c|c|c|c|c|c|c|}
\hline \multicolumn{7}{|c|}{ CONTENTS. } \\
\hline & & PAGE & & & & PAGE \\
\hline e Larv & . & 70 & 5. Comparison with Larvae & of & other & \\
\hline The Puparium &  & 73 & Phoridae & & & 74 \\
\hline The Pupa & . & 73 & 6. References to Literature & & & 74 \\
\hline Emergence of A & Adult from Puparium & 73 & 7. Description of Plate & & & 74 \\
\hline
\end{tabular}

ON Jan. 27th, 1920, among a number of nearly fully grown larvae of Bibio marci which had been kept in the laboratory about two weeks, a few individuals were observed to be unhealthy or dead. These latter were found to contain parasitic Dipterous larvae, which eventually proved to be those of Hypocera incrassata $\mathrm{Mg}$. Certain of these larvae were observed to be leaving the bodies of other larvae of Bibio marci at the same time.

The larvae of Hypocera incrassata pupated in the soil immediately after leaving their hosts, and only a single parasite was observed in each of the latter.

The pupae were kept in soil in the laboratory, and the adults emerged between June 24th and July 1st.

The larva and pupa of Hypocera incrassata appear to be undescribed. It is noteworthy that $H$. vitripennis is recorded as having been reared from humblebees' and wasps' nests (4), and H. vectabilis from dried specimens of Coleoptera (1).

The present species is of additional interest as being the first definite record of an insect parasitic on Bibionid larvae.

I am indebted to Dr D. Keilin for the identification of the adult flies, and for the information regarding previous records of the rearing of species of Hypocera. I am also much indebted to Dr A. D. Imms for advice during the preparation of this paper.

\section{THE LARVA.}

The larvae were not observed until they were leaving, or about to leave, the body of the host, and were then fully grown. At this stage they are about $8.0 \mathrm{~mm}$. to $8.5 \mathrm{~mm}$. in length and about $2.0 \mathrm{~mm}$. in breath, and are of a yellowish-white colour. 
External Form. The larva (Plate III, fig. 1) is composed of a small cephalic region, and eleven body segments, the segmentation being fairly distinct, but somewhat obscured by the presence of supplementary folds.

On the ventral surface of the cephalic region is a small opening, the mouth,

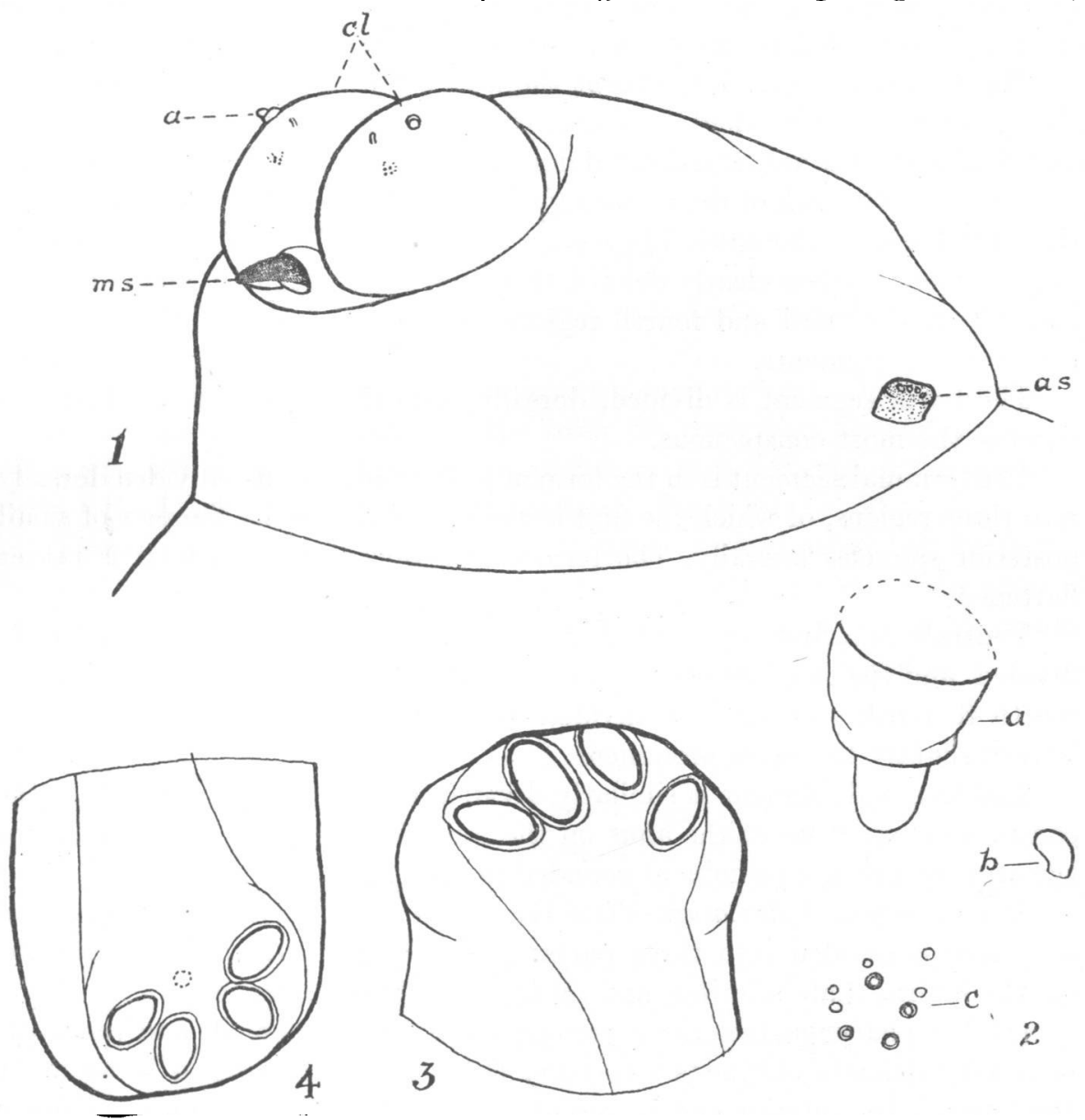

Text-fig. 1. Cephalic and prothoracic segments of larva of Hypocera incrassata Mg. Lateroventral view. $a_{*}$, antennal organ; as., anterior spiracle; $c l$, cephalie lobes; ms., mandibular selerite. $\times 32$.

Text-fig. 2. Sensory struetures on cephalic lobe. a., antennal organ; b., club-shaped projecting structure; $c$., group of papillae. $\times 670$.

Text-fig. 3. Anterior spiracle of larva of Hypocera incrassata $\mathrm{Mg} . \times 670$.

Text-fig. 4. Posterior spiracle of larva of Hypocera incrassata Mg. $\times 670$.

from which projects the single mandibular sclerite (Text-fig. 1). Dorsal to the mouth are a pair of hemispherical lobes, bearing sensory structures. The most conspicuous of these structures is the antennal organ, which consists of two segments, the basal segment of which is cylindrical, and the distal segment dome- or bell-shaped (Text-fig. $2 a$ ). 
Close to the antennal organ, but rather ventral to it, is a minute slightly curved and somewhat club-shaped projecting organ; near the latter there is also a small group of minute papillae (Text-fig. $2 b$ and $c$ ).

The first segment of the body is small and rather conical, and near its posterior margin is a pair of projecting lateral spiracles which are brown in colour. Dorsally this segment bears a slight median transverse depression.

The remaining segments, except the last, are cylindrical, and increase in size to the sixth, after which they are approximately equal in size. The second and third segments are each divided dorsally into two parts by a median transverse sulcus. On each of the following segments, from the fourth to the ninth, there are three similar sulci. The second and third of the regions so formed in each segment are less clearly defined than the first and fourth, and it may be added that the third and fourth regions inerease slightly in prominence on the posterior segments.

The tenth segment is divided, dorsally, into three regions, of which the third is the most conspicuous.

The terminal segment is in the form of a blunt cone, and is divided dorsally into three regions, of which the first is the largest and bears the pair of small posterior spiracles laterally. The terminal portion of this segment is rather flattened.

Ventrally, the first segment is undivided; the second segment is very faintly divided, and the third segment more distinctly divided into two regions. The fourth to tenth segments are divided into three regions, of which the first is very slightly the more prominent.

The terminal segment is similarly divided into three parts, and bears the conspicuous aperture of the anus on the foremost division. On each side of the anus is a rather prominent rounded fleshy process.

Buccopharyngeal Armature (Plate III, figs. 4 and 5). The buccopharyngeal armature is divided into three parts: (1) the pharyngeal.or basal sclerite, (2) the intermediate sclerites, and (3) the mandibular sclerite.

(1) The pharyngeal sclerite is prolonged posteriorly (dorsally and ventrally) as a very delicate chitinous structure, the dorsal prolongation being much the longer. Its anterior end is strongly chitinised and bears on each side a hollow for the articulation of the intermediate sclerite.

(2) The intermediate sclerites are stout and strongly chitinised and are not fused together. They articulate with the hollows at the anterior end of the pharyngeal sclerite by means of a hook-like prolongation at their posterior end.

(3) The mandibular sclerite is a single very stout structure. It articulates with the intermediate sclerites by means of a pair of backwardly directed divergent arms at its posterior end. Ventrally, near the base, it bears several slight transverse ridges suggestive of vestigeal teeth.

Articulating with a slight projection at the anterior external angle of either intermediate sclerite is a delicate process, more strongly chitinised at its base, 
and having the form shown in Plate III, fig. 6. At its distal extremity each process bears several projecting spines. These processes bear some resemblance to those described by Keilin (3) as "Baguettes orales" (oral rods) in carnivorous Anthomyid larvae.

Tracheal System. The tracheal system is amphipneustic, a pair of spiracles being situated on both the first and last segments of the body.

Both pairs of spiracles are very alike in size and structure and are brown, chitinised outgrowths from the body-wall: each spiracle communicates with the exterior by means of four oval apertures situated at its apex (Text-figs. 3 and 4).

\section{THE PUPARIUM.}

The puparium is brown, with the segments fairly clearly marked. It is about $5.0 \mathrm{~mm}$. in length.

Dorsally there are several conspicuous constrictions. The prothoracic spiracular horns of the pupa emerge from the puparium through a pair of holes situated in a somewhat lateral position on its dorsal side, at the posterior end of the fourth body segment of the larva (Plate III, fig. 2).

These horns are about $0.23 \mathrm{~mm}$. in length, and their distal half bears two rows of minute openings, about sixteen openings in each row. Both pairs of larval spiracles remain as conspicuous dark projections from the puparium, and the mandibular sclerite also projects at the anterior extremity.

\section{THE PUPA.}

The pupa, seen on removal from the puparium is white, with the appendages of the adult fly closely adpressed to the body. Its general characters can be seen on referring to Plate III, fig. 3, and scarcely need detailed description.

The head is of moderate size, and the antennae are large and are produced in a long slender process. The palpi are conspicuous and conical in shape. The labrum is short and flattened. The legs lie side by side, the tarsi of the posterior pair projecting slightly beyond the apex of the abdomen.

\section{EMERGENCE OF ADULT FROM PUPARIUM.}

When the adult fly emerges from the puparium, the latter is split in the following way. A circular cap, consisting of the skin of the cephalic region and thoracic segments of the larva, is split off by means of a fissure passing round the body between the third thoracic and first abdominal segments. A quadrangular plate is split off in addition, and it consists of the whole skin of the dorsal surface of the first three abdominal segments.

This plate may become completely detached, or may remain slightly adhering at its posterior end to the anterior margin of the fourth abdominal segment. 


\section{COMPARISON WITH LARVAE OF OTHER PHORIDAE.}

The larva of Hypocera incrassata differs considerably from the larvae of Phora Bergenstammi Mik., P. rufipes Mg., and P. ruficornis Mg., as described by Keilin (2).

The buccopharyngeal armature is very different as may be seen by comparison with Keilin's figures. The numerous sensory structures on the cuticle of the latter larvae are not present in the case of Hypocera incrassata.

The absence of sensory structures may be an adaptation to a more completely parasitic existence, as may also be the simpler buccopharyngeal armature, with the fusion of the usual two mandjbular sclerites into an unpaired organ.

The study of this larva lends support to the opinions of Brues, de Meijere and Keilin that the position of the Phoridae in the classification of the Diptera should be among the Cyclorrhapha.

\section{REFERENCES.}

(1) Brums, C. T. (1913). A New Species of Phoridae reared from dried Coleoptera. Ann. Mus. Nation. Hung. XI.

(2) KerLIv, D. (19II). Recherches sur la morphologie larvaire des Diptères du genre Phora. Bull. Sci. France et Belg. $7^{\mathrm{me}}$ série, T. xurv, i.

(3) KaILIn, D. (1917). Recherches sur les Anthomyides à larves carnivores. Parasitology, $\mathrm{IX}, 3$.

(4) Wood, J. H. (1906). On the British Species of Phora (Part I). Ent. Mon. Mag. Xvir.

\section{DESCRIPTION OF PLATE III.}

Larval and Pupal Stages of Hypocera incrassata Mg.

Fig. 1. Fully grown larva. Dorsal view, as., anterior spiracle; ps., posterior spiracle. $\times 20$.

Fig. 2. Puparium. Lateral view. ts., protruding spiracular horn of pupa. $\times 20$.

Fig. 3. Pupa removed from puparium. Lateral view. s., prothoracic spiracular horn. $\times 20$.

Fig. 4. Buccopharyngeal armature of larva. Lateral view. $i$, intermediate sclerite; $m$. , mandibular sclerite; $o$., "baguette orale"; $p$., pharyngeal sclerite. $\times 126$.

Fig. 5. Buccopharyngeal armature of larva. Ventral view. Lettering as in previous figure. $\times 126$.

Fig. 6. "Baguette orale" of larva $\times 730$. 

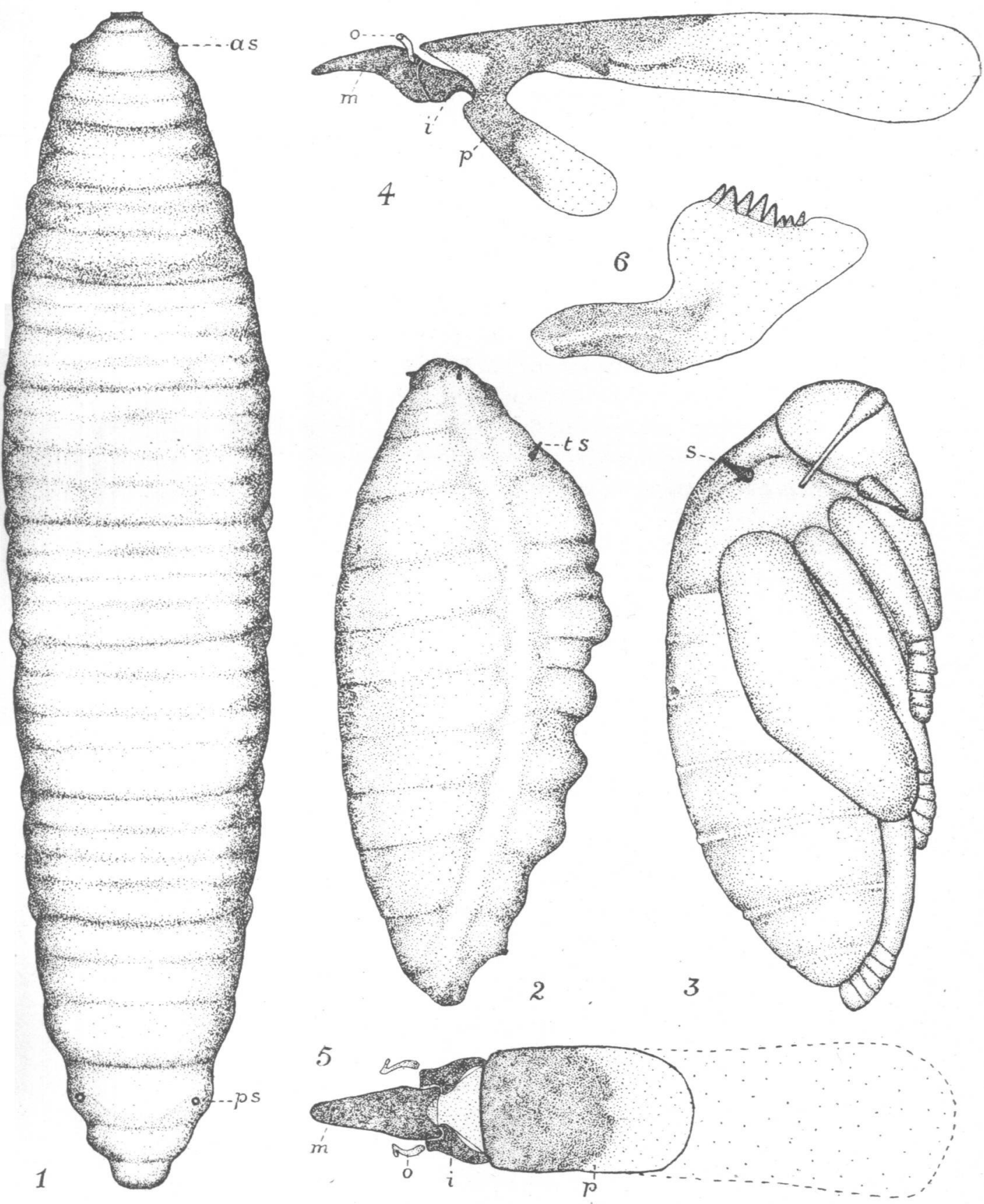

H. M. Morris del. 